\title{
EFFECT OF CHLOROPHYLL ON THE BIOLOGICAL ACTIVITY OF VITAMIN C
}

\author{
CHOTEN INAGAKI AND KIYOKO YAMAZAKI* \\ Department of Nutritional Chemistry, School of Home Economics, \\ Ochanomizu University, Bunkyo-ku, Tokyo and \\ * Department of Home Economics, Tokyo Gakugei \\ University, Bunkyo-ku, Tokyo.
}

(Received Feburary 27, 1956)

Since the establishment of the chemical structure of chlorophyll (Chl) as tetrapyrrole compounds similar to hemin, many studies have been made concerning the effect of $\mathrm{Chl}$ on living organisms and it is now being used as a medicine, etc. $\quad \mathrm{Chl}$ is also known to take part in the formation of vitamin $\mathrm{C}$ (VC) in vegetables, and, as Newbauer (1) pointed out, much $\mathrm{Chl}$ is found where much VC exists, suggesting the possible existence of some relations between $\mathrm{Chl}$ and $\mathrm{VC}$ also in animals. In order to investigate the effect of $\mathrm{Chl}$ on the biological activity of $\mathrm{VC}$, an experiment was performed using guinea pigs as test animals. One of the authors (2) has established by experiment the effective minimum requirement of one guinea pig for $\mathrm{VC}$ to be $0.5 \mathrm{mg}$ a day. The present authors tried to test the effect of $\mathrm{Chl}$ on the biological activity of $\mathrm{VC}$ and could confirm a definite promoting effect of $\mathrm{Chl}$ on the activity of $\mathrm{VC}$.

\section{EXPERIMENTAL}

\section{Test Animals and Feeds}

The animals used in this experiment were guinea pigs of both sexes weighing about $250 \mathrm{~g}$.

The basal feed consisted, in per cent, of bran 45, powdered oats 25 and dried milk (heated for 30 minutes at $120^{\circ}$ to exclude VC) 30 . At the same time two drops of cod-liver oil were given twice a week, and $1 \mathrm{~g}$ of powdered yeast once a week. For testing the effect following three chlorophyllin (Chln) preparations were employed, i.e., $\mathrm{Cu}-\mathrm{Ch} l n-\mathrm{Na}, \mathrm{Mg}-\mathrm{Chln}-\mathrm{Na}$ and $\mathrm{Fe}-$ Chln-Na. All these compounds, having 95-96 per cent purity, were prepared in the laboratory of Eizai K. K.

\section{Method}

The guinea pigs were divided into the following 13 groups, each consisting of 3 animals of both sexes. The 1 st group: $0.5 \mathrm{mg}$ L-ascorbic acid (AA) plus $1 \mathrm{mg} \mathrm{Cu}-\mathrm{Chln}-\mathrm{Na}$. The $2 \mathrm{nd}: 0.5 \mathrm{mg}$ AA plus $0.5 \mathrm{mg} \mathrm{Cu}-\mathrm{Chln}-\mathrm{Na}$. The 3rd: $0.5 \mathrm{mg}$ AA plus $5 \mathrm{mg} \mathrm{Cu-Chln-Na.} \mathrm{The} 4$ th: $5 \mathrm{mg} \mathrm{Cu}-\mathrm{Ch} l n-\mathrm{Na}$ without 
AA. The 5 th: $10 \mathrm{mg} \mathrm{Cu}-\mathrm{Ch} \ln -\mathrm{Na}$ without AA. The 6 th: $0.5 \mathrm{mg}$ AA plus $1 \mathrm{mg} \mathrm{Mg}-\mathrm{Ch} l \mathrm{n}-\mathrm{Na}$. The $7 \mathrm{th}: 0.5 \mathrm{mg}$ AA plus $1 \mathrm{mg}$ Fe-Chln-Na. The 8 th: leef vegetables, Brassica chinensis L. var. Komatsuna Matsum., containing $0.5 \mathrm{mg} \mathrm{AA}$. The $9 \mathrm{th}$ : bean sprouts containing $0.5 \mathrm{mg}$ AA. The 10 th: 0.5 mg AA plus ferric citrate. The 11 th: $0.5 \mathrm{mg}$ AA added with $\mathrm{CuSO}_{4}$. The 12th: AA $1 \mathrm{mg}$. The $13 \mathrm{th}:$ AA $0.5 \mathrm{mg}$. Each animal was placed in a wire cylinder, $27 \times 30 \mathrm{~cm}$, straws being spread on the bottom. The straws were renewed every three days.

As the preparatory experiment each guinea pig was fed the mixture of bran and bean curd lees "tofu", gradually adding increasing amounts of the basal feed and weeds and decreasing the former mixture till it was entirely omitted. When the animals were accustomed to the basal feed, weeds were excluded. Then the experiment started by feeding the basal feed and water together with the test food, and each animal was weighed once a day at a definite time.

The test foods were prepared as follows: In AA groups, 3 drops of aqueous AA solution containing 0.5 or $1 \mathrm{mg}$ were given. In Chln groups, $0.5 \mathrm{mg}$ $\mathrm{AA}$ and $0.5,1$ and $5 \mathrm{mg}$, respectively, of $\mathrm{Cu}-\mathrm{Chln}-\mathrm{Na}$ were given. Other groups received $1 \mathrm{mg} \mathrm{Mg}-\mathrm{Chln}-\mathrm{Na}$ and $1 \mathrm{mg} \mathrm{Fe}-\mathrm{Chln}-\mathrm{Na}$. The 4 th group received $5 \mathrm{mg} \mathrm{Cu}-\mathrm{Ch} / \mathrm{n}-\mathrm{Na}$ alone and the $5 \mathrm{th} 10 \mathrm{mg} \mathrm{Cu}-\mathrm{Chln}-\mathrm{Na}$. Only the leaves of the greens and the stalks of bean sprouts were given to the 8 th and 9 th groups, each containing $0.5 \mathrm{mg}$ AA. The Fe group (10 th) received 0.389 $\mathrm{mg}$ ferric citrate containing the amount of $\mathrm{Fe}$ contained in $1 \mathrm{mg} \mathrm{Fe}-\mathrm{Chln}-\mathrm{Na}$ together with $0.5 \mathrm{mg} \mathrm{AA}$; and $\mathrm{Cu}$ group (11th), $0.365 \mathrm{mg} \mathrm{CuSO}+$ containing the amount of $\mathrm{Cu}$ corresponding to $1 \mathrm{mg} \mathrm{Cu}-\mathrm{Chln}-\mathrm{Na}$ in addition to $0.5 \mathrm{mg}$ AA. All these chemicals were given as a solution using phials.

The experiment consisted of 7 periods. The 1 st period was from May to July, 1951. The 2 nd, from October to November, 1951. The $3 \mathrm{rd}$, from September to November, 1952. The 4 th, from May to July, 1953. The 5 th, from September to November, 1953. The 6 th and 7 th, from April to June, 1954. Each period lasted 40-60 days, during which appetite, weights, motion and appearances of the animals were observed.

\section{Results}

The results of the experiment as given in Table I, as well as Fig. 1 and 2 show that $0.5 \mathrm{mg}$ AA group (13 th) gained on an average only $0.7 \mathrm{~g}$ in weight per day, while those groups receiving $1 \mathrm{mg}$ each of $\mathrm{Cu}-\mathrm{Ch} / \mathrm{n}-\mathrm{Na}, \mathrm{Mg}$ $\mathrm{Chln}-\mathrm{Na}$ and $\mathrm{Fe}-\mathrm{Chln}-\mathrm{Na}$ respectively gained $3.6,3.2$ and $2.9 \mathrm{~g}$ indicating far more beneficial growth and apparent health of the groups of Chln addition than the group without addition. Moreover, those groups receiving 1 or 5 $\mathrm{mg} \mathrm{Cu}-\mathrm{Ch} / \mathrm{n}-\mathrm{Na}$ and $1 \mathrm{mg} \mathrm{Mg-Chln}-\mathrm{Na}$ together with $0.5 \mathrm{mg}$ AA gained almost as much as $1 \mathrm{mg}$ AA group (12 th). The group receiving $5 \mathrm{mg} \mathrm{Cu}-\mathrm{Ch} / \mathrm{n}-\mathrm{Na}$ together with $0.5 \mathrm{mg}$ AA ( $3 \mathrm{rd}$ ) gained $3.3 \mathrm{~g}$ per day, a somewhat less weight gain than the group receiving $1 \mathrm{mg} \mathrm{Cu}-\mathrm{Ch} l n-\mathrm{Na}(1 \mathrm{st})$. No remarkable effect corresponding to a five-fold amount of $\mathrm{Cu}-\mathrm{Ch} / \mathrm{n}-\mathrm{Na}$ was observed. The excrements of the 1 st group were light brown in color while those of the $3 \mathrm{rd}$ one were dark green, possibly the excess Chln being excreted undigested. 
TABLE I

Effect of Chlorophyllin on the Growth of Guinea Pigs.

\begin{tabular}{|c|c|c|c|}
\hline Group & Treatment & $\begin{array}{l}\text { Initial average } \\
\text { weight }\end{array}$ & $\begin{array}{l}\text { Average weight } \\
\text { gain per day }\end{array}$ \\
\hline & & $g$ & $g$ \\
\hline 1 & $\mathrm{AA} 0.5 \mathrm{mg}+\mathrm{Cu}-\mathrm{Chln}-\mathrm{Na} 1 \mathrm{mg}$ & 220.5 & 3.6 \\
\hline 2 & $\mathrm{AA} 0.5 \mathrm{mg}+\mathrm{Cu}-\mathrm{Ch} l \mathrm{n}-\mathrm{Na} 0.5 \mathrm{mg}$ & 248.3 & 2.3 \\
\hline 3 & $\mathrm{AA} 0.5 \mathrm{mg}+\mathrm{Cu}-\mathrm{Chln}-\mathrm{Na} 5 \mathrm{mg}$ & 252.3 & 3.3 \\
\hline 4 & $\mathrm{Cu}-\mathrm{Chln}-\mathrm{Na} 5 \mathrm{mg}$ & 269.7 & -0.4 \\
\hline 5 & $\mathrm{Cu}-\mathrm{Ch} \ln -\mathrm{Na} 10 \mathrm{mg}$ & 251.3 & 0.9 \\
\hline 6 & AA $0.5 \mathrm{mg}+\mathrm{Mg}-\mathrm{Chln}-\mathrm{Na} 1 \mathrm{mg}$ & 267.8 & 3.2 \\
\hline 7 & AA $0.5 \mathrm{mg}+\mathrm{Fe}-\mathrm{Ch} l \mathrm{n}-\mathrm{Na} 1 \mathrm{mg}$ & 254.5 & 2.9 \\
\hline 8 & Komatsuna containing AA $0.5 \mathrm{mg}$ & 265.0 & 2.7 \\
\hline 9 & Bean sprouts containing AA $0.5 \mathrm{mg}$ & 216.1 & 1.8 \\
\hline 10 & $\mathrm{AA} 0.5 \mathrm{mg}+\mathrm{FeC}_{8} \mathrm{H}_{5} \mathrm{O}_{7} 0.389 \mathrm{mg}$ & 264.3 & 2.1 \\
\hline 11 & $\mathrm{AA} 0.5 \mathrm{mg}+\mathrm{CuSO}_{4} 0.365 \mathrm{mg}$ & 260.0 & 1.7 \\
\hline 12 & AA $1 \mathrm{mg}$ & 309.3 & 3.8 \\
\hline 13 & AA $0.5 \mathrm{mg}$ & 238.0 & 0.7 \\
\hline
\end{tabular}

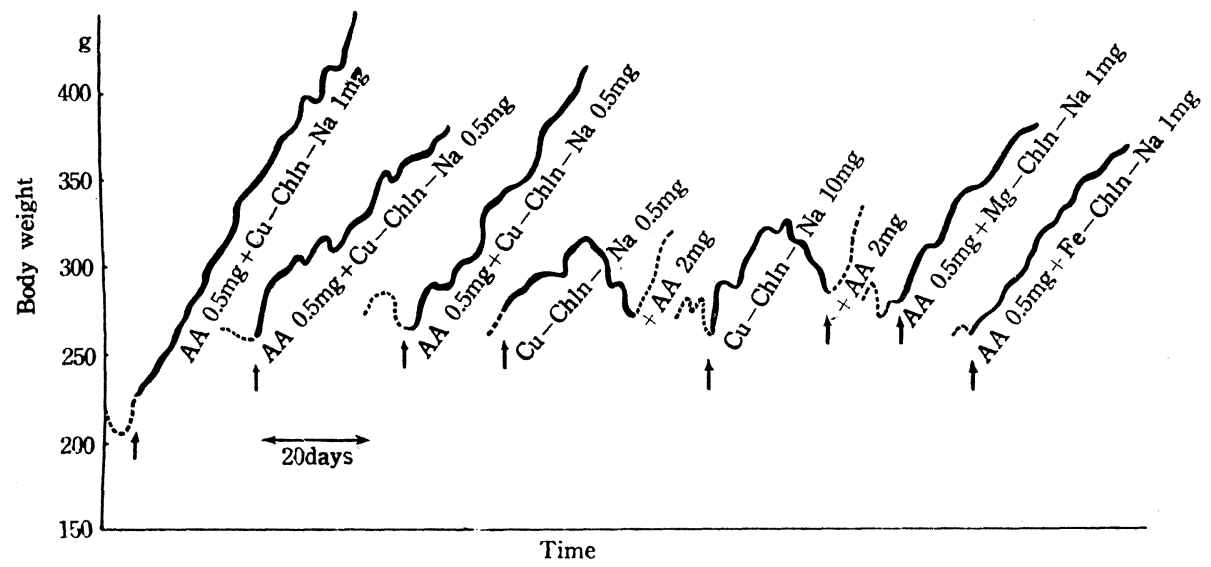

Fit. 1 Animal Experiment Using Chlorophyllin Preparations together with Ascorbic Acid.

The group receiving $0.5 \mathrm{mg} \mathrm{Cu}-\mathrm{Ch} / \mathrm{n}-\mathrm{Na}(2 \mathrm{nd})$ gained $2.3 \mathrm{~g}$ per day, being less than the $1 \mathrm{st}$ group. The groups receiving 5 or $10 \mathrm{mg} \mathrm{Cu}-\mathrm{Chln}-\mathrm{Na}$ alone began to lose weight after 16-18 days, without appetite, and too inactive to move. After feeding $2 \mathrm{mg}$ AA, they became suddenly active and gained weight. The group fed green leaves $(8 \mathrm{th})$ gained $2.7 \mathrm{~g}$, more marked than $0.5 \mathrm{mg}$ AA group (13 th), but less than the 1 st group receiving $0.5 \mathrm{mg}$ AA plus $1 \mathrm{mg} \mathrm{Cu}$ $\mathrm{Chln}-\mathrm{Na}$. This suggests that green leaves containing $0.5 \mathrm{mg}$ AA may possess less than $1 \mathrm{mg}$ Chln.

The bean sprouts group ( 9 th) containing no $\mathrm{Chl}$ gained more in weight 


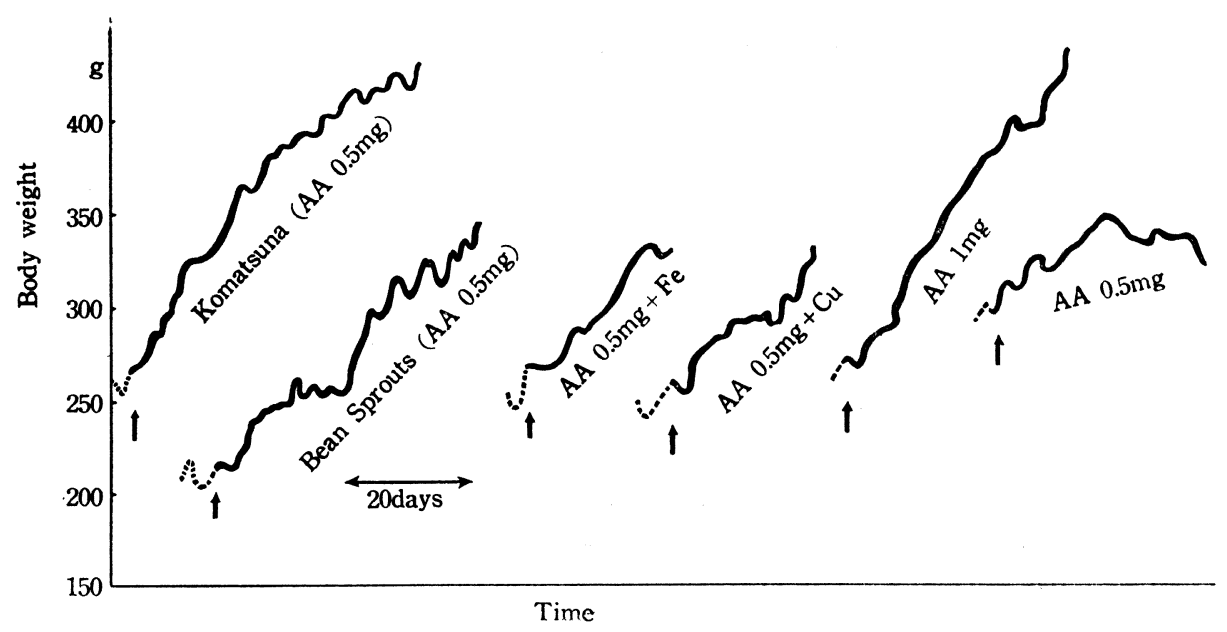

FIG. 2 Animal Experiment with Ascorbic Acid.

than $0.5 \mathrm{mg}$ AA group (13 th), though less than the groups receiving Chln or green leaves, possibly suggesting that vegetables have other supplementary components which are more effective than synthetic Chln. It is worthy of note that these vegetables (green leaves and sprouts) were eaten at once by the animals as soon as they were given.

The effects of inorganic salts which were contained in Chln preparations, i.e., $88.6 \gamma, \mathrm{Fe}$ and $144.7 \gamma \mathrm{Cu}$ respectively, were tested as $\mathrm{FeC}_{6} \mathrm{H}_{5} \mathrm{O}_{7}$ and $\mathrm{CuSO}_{4}$ but it proved to be less effective than Chl (Table I).

\section{SUMMARY}

1. The effect of $\mathrm{Chl}$ on the biological activity of vitamin $\mathrm{C}$ was tested using guinea pigs and it was proved that the animals receiving $0.5 \mathrm{mg}$ ascorbic acid (minimum requirement) together with $1 \mathrm{mg} \mathrm{Chl}$, showed the effect corresponding to those receiving $1 \mathrm{mg}$ ascorbic acid alone.

2. Administration of $\mathrm{Chl}$ alone even in a large amount could never prevent vitamin $\mathrm{C}$ deficiency.

3. When vitamin $\mathrm{C}$ is administered as natural vegetables, the effect of Chl plus vitamin $C$ (green leaves) proved to be more effective in gaining body weight than that of the vitamin alone (bean sprouts).

\section{REFERENCES}

1. Newbauer, M., Protoplasma 33, 345 (1939).

2. Inagaki, Ch., Vitamin C in Natural Vegetables (Japanese). p. 79, Sangyo-Tosho, Tokyo, (1948). 